\title{
A Meta-Baroque Allegory for an Architectural Concept
}

\author{
By Maria João Soares ${ }^{*}$
}

\begin{abstract}
This paper makes an argument for a reactive architecture - as an architectural apparatus or a "meta-machine" - in which the body is the active element of a metamorphosis. The meta-Baroque concept is, in this circumstance, at the core of this reactive architecture. It is its maxim. As that maxim derives from the universe of Gilles Deleuze, in particular the allegory of the Baroque House, and Deleuze and Guattari's Desiring-Machines, it is a rather abstract one, one that is embedded in a transdisciplinary mesh. It is a concept that evolves around the idea of a specific house that resides in our body, as something close to our soul. A house dissolved into an interior universe; open. It is this state of being open that will give rise to the meta-Baroque concept: a changeable architecture, in space and time, connected with the centre of our body through continuous inter-connections, as a new house-machine. In addition to the philosophical aspects, the transdisciplinary mesh that supports the meta-Baroque requires reinforcement from two more protagonists: Kurt Schwitters and his Merzbau - a universe of interiority in a constant alteration fold, an intraworld; and Louise Bourgeois and her Femme Maison - as a testament to (our/her) body as a home, an intrabody. These inter and trans-relationships will guide us on the continuous path to a world-a meta-Baroque world. As Muriel Combes puts it: going from knowing the relation to knowing as relation.
\end{abstract}

\section{Home Address}

he who walks with his house on his head is heaven he who walks with his house on his head is heaven he who walks with his house on his head

(Charles Olson, Maximus II, 1956)

Hanover, Waldhausenstrasse, 5a. New York, 347 West, 20 ${ }^{\text {th }}$ Street. Two addresses, two houses. Houses lived in by two artists in different periods, different geographic spaces: Kurt Schwitters (1887-1948) and Louise Bourgeois (19112010).

These protagonists - Schwitters and Bourgeois - and their oeuvre provide the rationalization for this work on concepts concerning the body and its place; and the body as place - its interiority, and the reverse of that interiority - and how that double circuit of reciprocity (interior/exterior/interior) can establish a given architectural argument. Here it is important to reference the growing

* Auxiliar Professor, CITAD, Lusíada University, Portugal. 
importance of the work of Kurt Schwitters from the late $20^{\text {th }}$ century onwards, particularly in the context of architecture. Also, the fundamental role that Louise Bourgeois has played in the context of thought in general, and the arts in particular, in the late $20^{\text {th }}$ and early $21^{\text {st }}$ century.

However, to establish the premises for the argument presented herein one also needs to include other authors: the philosophers Gilles Deleuze (19251995), in particular a specific part of his work, the allegory of the Baroque House he develops in his book Le Pli: Leibniz et le Baroque (1988) (The Fold: Leibniz and the Baroque); and Félix Guattari (1930-1992), more specifically the Desiring-Machine concept that he and Deleuze developed in their book L'anti-Edipe: capitalisme et schizophrénie (1972) (The Anti-Oedipus: Capitalism and Schizophrenia). In said allegory, Deleuze establishes a very particular image of a house that is closed in on itself, for itself. This closing action leads to a world that is also folded in on itself: an intraworld that in turn manifests itself in an intrabody. The house proposed by Deleuze, via Leibniz, "lives" in us, in our body, representing something metaphysical that is close to the concept of soul, the monad. A house residing at the top of our bodies, folded in on itself, interiority of interiority, but open - open to velocity and its unending possibilities. The plastic capacity of the fold offers the Deleuzian house the eventuality of opening in the abysses of our being. To be, in this sense, is to be open; it is to be open to... It is this state of being open, dynamically open, that is to give rise to the concept of meta-Baroque, which is precisely reaffirmed in an intrabody that converges in an intraworld in constant movement. As this idea of constant movement takes form, it is the notion of the machine that comes to the fore, but not mechanical machinery. Here, in this open, folded meta-Baroque world, we need a new machine, one that can operate as a post desiring-machine, as an architectural apparatus in constant metamorphosis, as will be shown later.

The houses in Hanover and New York are themselves the result of the experiences of Schwitters and Bourgeois. Experiences knitted by their bodies or intrabodies - as "(re)actors" in an intraworld. And they, their houses, their bodies of work, are on the route towards defining the desiring-machine, something close to a living machine. They, these houses, come close to what can be considered as a path towards a meta-Baroque maxim.

\section{The Meta-Baroque}

In the architectural context, Deleuze's, Le Pli: Leibniz et le Baroque has been the subject of many references and theoretical developments centring around the Deleuzian fold - from Bernard Cache to Peter Eisenman and to Greg Lynn and even to Anthony Vidler:

In his exploration of the spatial characteristics of Leibniz's philosophy considered as "baroque," Gilles Deleuze introduced what has proved to be a provocative form theme for contemporary architects: that of the "fold" or 
pli, registered both as material phenomenon - as in the folds of Bernini's sculpture of Santa Teresa, for example, - and as a metaphysical idea as in the "fold" that joins the soul to the mind without division. ${ }^{1}$

This reflects the relevance of the subject matter, though the approach taken herein, in its reading of the Deleuzian fold, will follow new paths that are not centred on the application of a model to an already built work or on the development of a formal tendency specific to this new century. Rather, it will highlight a theoretical core as a basis for a possible new approach to architecture.

The aim is to turn the whole Leibnizian model proposed by Deleuze into a mobile, weaving a mesh of imponderabilities made up of desires of unpredictable pre-designation, establishing a set of hypotheses that ensures a fundamental aesthetic quality in the practice of architecture. This aesthetic quality establishes itself at the core of the body, or rather at the core of the intrabody. By intrabody is meant a superimposed enchainment of soul, mind and flesh, in succession, or progression, without boundaries, without limits. Intrabody is an enhanced version of our bodies. Our inner selves draining into our outer selves and again into our inner selves in constant motion. This is the body that is claimed for the metaBaroque. Moreover, in meta-Baroque, the body comes to the fore as a mobile, as the body that becomes responsible for the consequences and options of a specific architectural endeavour that can be called an architectural apparatus something close to a machine, machinic. The body in movement is the beginning - all mobile, all in coalescence. It is trajective. ${ }^{2}$ One can call this process the search for a dromography that is at the root of the architectural design project, an appeal for trajectivity and for the study thereof.

It is our understanding that architecture could come to assert itself as something dependent on - and thus reactive to - stimuli from the body. In other words, architecture in metamorphosis as a result of the intuitive (to varying degrees) intentions of the body. Architecture "at rest/metamorphosed/at rest" based on dromographic readings proposed by the body.

Deleuze himself heralded a new Baroque:

[...] we have a new Baroque and a neo-Leibnizianism. The same construction of the point of view over the city continues to be developed, but now it is neither the same point of view nor the same city, now that both the figure

1. A. Vidler, Warped Space. Art, Architecture, and Anxiety in Modern Culture (Cambridge: MIT Press, 2001), 219.

2. Trajective and trajectivity are terms used by Paul Virilio in an interview with Laurence Louppe and Daniel Dobbles: "This explains my interest in vision machines, in the technologies of perception that escape gravity, because this is an automated perception, a perception by recognition of forms, which comes about through the marriage of a computer and a camera. It is therefore true that there is a reinvention of the body's weight, but in my opinion it ought to go much further, philosophically speaking: between the subject and the object what's always missing is the trajectory. I mean this is in a very concrete way: we have to rediscover its meaning, to the point where I now speak of the trajective, of trajectivity, in the same way one speaks of the object, the objective, objectivity." P. Virilio, "Gravitational Space," in Traces of Dance (ed.) L. Laurence (Paris: Editions Dis Voir, 1994), 38-39. 
and the ground are in movement in space. Something has changed in the situation of monads, between the former model, the closed chapel with imperceptible openings, and the new model invoked by [the artist] Tony Smith, the sealed car speeding down the dark highway. ${ }^{3}$

Vidler writes about a neo-baroque house - one that should overcome the modernist solution to the monad (Le Corbusier's chapel at La Tourette is the example given by Deleuze) and the postmodernist solution (Vidler gives the example of Colin Rowe's Collage City, with its stable interplay of figure and ground). These examples, according to Vidler, should be supplanted by a folded city: ${ }^{4}$

One that moves beyond the traditional antinomies of modernism - implied conflict between the "bearing principle" and the "covering principle," between, as Deleuze hazards, Gropius and Loos - and establishes a postleibnizian house for a new "harmony" of inside and outside. But where the modernist "baroque" drew on the spatial ambiguities of its seventeenthcentury antecedent on behalf of a synthesis between space and time, for Deleuze the new baroque house exists to join animate and inanimate, to fold the one into the other with insistent force. ${ }^{5}$

In this context, one is more concerned with the action - or consequence of the fold's movement rather than the folds themselves. While moving from fold to fold, one can imagine the layering of matter as a juxtaposition of space and time, to the point that this "matter" is metamorphosed through trajectivity. Moving from something to another "something", pressing on through synthetized space and time. Remarkably Deleuze states, that, to survive, Karlheinz Stockhausen's musical habitat does not allow differences between inside and outside, public and private-likewise, Jean Dubuffet's plastic habitat. "They identify variation and trajectory, and overtake monadology with a 'nomadology.' Music has stayed at home; what has changed now is the organization of the home and its nature." Surviving through movement as transformation. Could one argue that, to survive, the architectural habitat must overcome the same differences? Vidler argues: "[...] above-ground and below-ground, private inside and public outside are forced into each other [...]." ${ }^{, 7}$ Perhaps one can go further: the body, as an intrabody, and the architectural object, above-ground and below-ground, private inside and public outside, are forced together resulting in an architectural apparatus in constant metamorphosis. It is trajective. One is in the realm of the "nomadology" - being mobile, at its core. This could lead one to a meta-Baroque world, where the "nomadology" craves for a home, for a house. And this house is something close to a living-in-a-living-object - a

\footnotetext{
3. G. Deleuze, The Fold (trans.) Tom Conley (London, Continuum, New York, 2006), 157.

4. Vidler, Warped Space: Art, Architecture, and Anxiety in Modern Culture, 2001, 233.

5. Ibid, 231.

6. Deleuze, The Fold, 2006, 158.

7. Vidler, Warped Space: Art, Architecture, and Anxiety in Modern Culture, 2001, 233.
} 
house in a constant process of change through reaction to being, through reaction to the human condition. A living machine.

This is the active substance of a meta-Baroque House, this is the argument put forward herein - or at least part of it.

\section{Intabodies and Intraworlds}

In order to strengthen the core - and the aesthetic nature - of this argument, let us return to the original protagonists, Kurt Schwitters and Louise Bourgeois, and their own houses. This core calls for a transdisciplinary mesh woven through Deleuze's philosophy but also through the oeuvre of these two artists. An aesthetic transdisciplinary mesh that should provide the deep roots for the thesis presented, articulating philosophical conceptual questions, not only through Deleuzian thought, but also through the crossing of the intraworlds and the intrabodies of Kurt Schwitters and his Merzbau, a universe of interiority in a constant changing fold, and Louise Bourgeois and her Femme Maison, as a witness of (our/her) body as a home.

\section{Kurt Schwitters}

Stone upon stone is a building.

But not as sum, building is form.

Building is form out of mass and space.

The hands create the form and give it color. Though they give more: Time.

Creating hands give to space everything the person who creates it, is: His world.

In the form, the play of forms, of colors, of images, of laws, yes, even the things that are not named in the building, time lives in space for all times. Thus space becomes a parable for time and points toward eternal creation.

(Kurt Schwitters, Stone upon stone is a building, 1934 - translated by Pierre Joris)

Pierluigi Nicolin writes the following about Schwitters'Merzbau - ten enormous columns which were referred to by its author as a Kathedrale des eroticshen Elends (Cathedral of Erotic Misery) -, his life's opus (see Figure 1):

How can I explain, to myself and others, the attraction of certain proposals that look like dreams, like representations of a devastated and in a way terrifying construction site? We neither know whether these constructions countenance completion, nor do we know if, should someone miraculously succeed in doing so, the result would be capable of evoking that totality of which we admire the disaster, its ruins, its wreckage. The new and irresistible 
fascination of the incomplete, with its origins somewhere in the Romantic tradition, certainly does not fit into the twentieth-century formulation, or rather label, of the "work-in-progress."

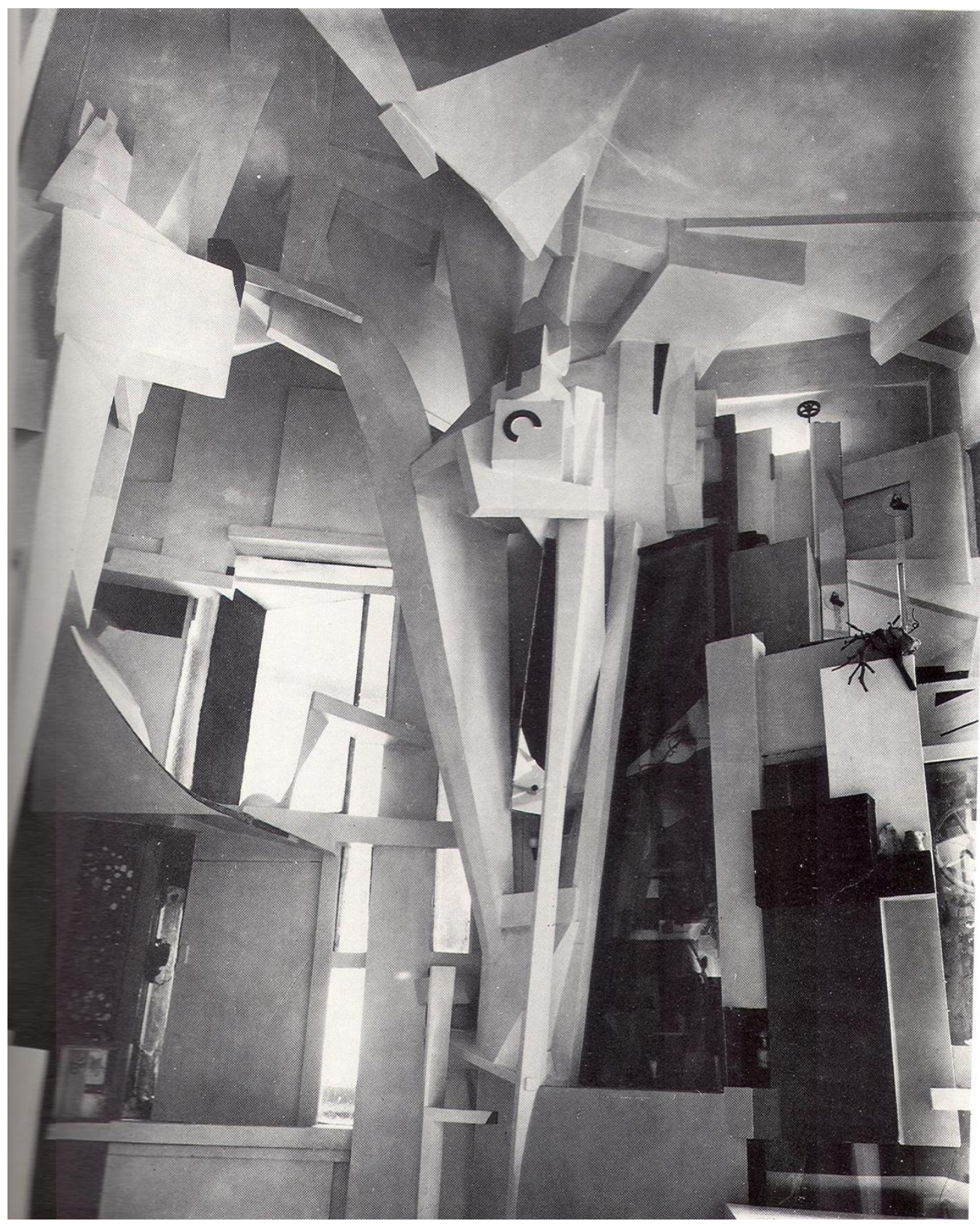

Figure 1. Segment of the Hanover Merzbau by Kurt Schwitters.Destroyed (1943). Photo: Wilhelm Redemann, 1933.

Source:https://artedeximena.files.wordpress.com/2010/10/wd-hannover-merzbau-1930-kurtschwitters.jpg.

This representation of devastation, or even decay, is something that Schwitters started to work on as early as 1923, developing the theme further until 1936

8. P. Nicolin, "Merzbau," in Lotus International, no.123 (Editoriale Lotus, 2005), 13. 
when he was forced to leave Germany - the first escape from the reigning terror regime. It was destroyed in a night-time Allied bombing raid in October 1943. Schwitters' Merzbau was built in his studio, at his family home at Waldhausenstrasse 5a in Hanover. His studio was to become his original laboratory. Very soon, it had gone beyond its own limits, his laboratory extending into the living quarters. "[...] eight rooms had been 'merzed,' [...]." "Merzed," like a disease. A virus.

Jaleh Mansoor writes:

[...] the ceaseless transformation, or careful construction and destruction, of the artist's studio as well as its vertically and horizontally adjacent rooms, into an all-encompassing environment. The internal space was consistently altered through the aggregation of found materials and objects, as well as the accumulation of purposive sculptural forms permanently affixed to the architectural container, the walls, ceiling, and floor. ${ }^{10}$

This internal disease was one without an end. ${ }^{11}$ That state of incompleteness was its essence: " $\mathrm{t}] \mathrm{h}$ he Merzbau remained unfinished 'as a matter of principle,' [...]."12 A year into his exile in Norway, Schwitters began to reconstruct the Merzbau - or a second Merzbau; later, in 1951, this second attempt was consumed by a fire. In 1947, now in England, he began a third and final effort named Merz Barn, housed in a former barn. It was also not completed. He died in 1948.

The Merzbau or Cathedral of Erotic Misery, was the inflated version of Merz, his concept for a total work of art (Gesamtkunstwerk), marrying different genres to create an artistic unity. For example, he organized words and sentences poetically in such a rhythmical composition that the result would be close to a drawing. Or he made collages with pictures and drawings that would result as texts. Pictures perforated by nails. Reliefs. Textures. As Schwitters himself put it: "I did this in order to erase the boundaries between the arts."13 The same principle was applied to his studio infecting, later, his apartment, only this time the result was an inverted construction process - a deconstructed rêverie - where the collage process explodes into the space. A chaotic aggregation of materials, objets trouvés, relics on display, as grotesque columns, as an infestation. Infestation as an experience on the human scale, one that one could walk around in. The construction process of the Merzbau was thus fortuitous. There was no specific system. But there was a clear intention of constructing a piece of Merz architecture by accumulation - evoking the

9. Ibid, 14.

10. J. Mansoor, “Kurt Schwitters' Merzbau: The Desiring House," in Lotus International, no.123 (Editoriale Lotus, 2005), 52.

11. When it was destroyed the Hanover Merzbau was incomplete.

12. D. Elger, "The Merzbau and Expressionist Architecture," in Merz World: Processing the Complicated Order (ed.) A. Notz and H. Obrist (Zurich: JRP Ringier, 2007), 16.

13. Kurt Schwitters cited in Rothenberg, Jerome and Joris, Pierre, "The Man in the Myth" in J. Rothenberg and P.Joris, eds., Kurt Schwitters: PPPPPP Poems, Performance, Pieces, Proses, Plays, Poetics (Cambridge: Change, 2002), xv. 
very foundations of the entire Merz aesthetic. This enormous materialized disease gave way to all forms of folds - inwards and outwards - and gaps or cavities, or grot toes opened up as mementos for Piet Mondrian ${ }^{14}$, “[...] Hans Arp, Theo van Doesburg, El Lissitzky, Mies van der Rohe ${ }^{15}$ and so on. ${ }^{16,17}$ It was a process of layering. Layer upon layer. Elements were inserted between these layers, partly walled up. A three-dimensional collage made in depth. A non-system in profoundness, in interiority, spreading itself and engulfing space through the flux of time as a monstrous growth. "The sole single principle or law to which the project adhered was continuous fluid production, a dynamic additive and subtractive process of connecting." ${ }^{18}$ An infected intraworld spreading in an intrabody.

As Nicolin argues:

[...] Merz architecture, with its gigantism fuelled by avant-garde ideas and utopias, offers in the fortuitousness of its systems, in the principle of montage, in the kaleidoscopic results, the harbingers of a new "edification," an opening up to the new adventures of a formal vocabulary, the search for an architecture for a new and potentially limitless metropolitan space. ${ }^{19}$

And Kurt Schwitters declares:

I demand Merz architecture. This demand has two aspects: 1. Merz design in architecture. 2. Merzian application of architecture to create new form. More than any other category of art, architecture is intrinsically attuned to the Merz idea. As we know, Merz means the use of pre-existing old material to create a new work of art. Because of the unwieldiness of the materials with which houses are built, architecture had no other option than always to reuse the old and incorporate it into the new design. ${ }^{20}$

14. "[Schwitters] dedicated a grotto in the Merzbau to Mondrian well before they ever met personally, which they eventually did, once, in March 1936, when he visited him in his studio in Paris with Arp.” M. R. Luke, Kurt Schwitters: Space, Image, Exile (Chicago: University of Chicago Press, 2014), 69.

15. Circa 1927, Schwitters gave a lecture in Frankfurt in which he showed Mies van der Rohe's design for the Brick Country House, 1924: "This building, he argued, does not treat space as an enclosure defined by its walls but rather radiates out from a situated center. Of all the architectural examples that he provided in his lecture at Frankfurt, only this structure really met his criterion of a 'new constructive form' that consisted of intersecting planes and was built from the inside out [...]." Ibid, 73.

16. "Several commentators have relished the notion that Schwitters furtively stole objects from his friends to include in the grottoes: fetishistic talismans like Sophie Taeuber-Arp's bra and a lock of Hans Richter's hair, or phallic objects like Mies's drafting pencil and Steinitz's house key. Yet Hanna Höch, for one, insisted on the consciously collaboration nature of the enterprise." Ibid, 109.

17. Nicolin, "Merzbau," 2005, 14.

18. Mansoor, "Kurt Schwitters' Merzbau: The Desiring House,” 2005, 52.

19. Nicolin, "Merzbau," 2005, 17.

20. Friedhelm Lach, Kurt Schwitters, Das LiterarischeWerk 5 (Cologne: DuMont Schauberg), 1973-1981, 95f; Schwitters cited in H. Orbist, "The Merzbau as a Paradigm of Interior Complexity," in Merz World: Processing the Complicated order (ed.) A. Notz and H. Obrist (Zurich: JRP Ringier, 2007), 7. 
One can imagine Schwitters proclaiming these demands: the same face that dictates his Ursonate (Merz\#24, 1932). Mouth wide open. Semi-closed eyes. He is his voice. He is his work. He is a "merzed" man. He has a virus. He is his Merzbau ${ }^{21}$ - an intraworld that spawns an intrabody. "All that remains of this work, defined by Hans Richter as his 'purest and most anti-commercial creation,' is a couple of photographs. As Richter put it: 'In reality the total work of art was him: Kurt Schwitters." ",22

\section{Louise Bourgeois}

My name is Louise Bourgeois.

I was born 24 December 1911, in Paris.

All my work in the past fifty years, all my subjects, have found their inspiration in my childhood.

My childhood has never lost its magic,

it has never lost its mystery,

and it has never lost its drama.

(Louise Bourgeois, Louise Bourgeois: Album, 1994)

The buildings, or more exactly, the Houses - and their/her memories - are one of the most prevalent themes in Louise Bourgeois's artistic output. The theme runs through her work, as a constant, for more than sixty years. The houses of her long life. She has drawn - and/or sculpted - most of them, from memory, or using documents that she kept for decades. On a single piece of paper she drew - as part of the The Insomnia Drawings from 1994 - facades of seven houses, or maisons, in her life; they are drawn on lined paper with little notes in Bourgeois's deliberately infantile handwriting: "Le Cabannet, Jardin Bonnard, montagne"; "aubusson, Jardin, côté Rue, Rivière"; "choisy, jardin, porte, cochère Rivièr"; "antony, jardin, porte, cochère, Rivière" and also "antony, Legrand, jardin + cotteur, serre"; "Easton, jardin"; "New York, côté jardin."23 Beatriz Colomina ${ }^{24}$ states that if these drawings are self-portraits then this work is a group portrait of all the different "Louise Bourgeois" over time. As if the buildings, or houses, could be seen as Bourgeois herself in the timeline spanning almost a century - that is her life. A century filled with memories, a life repaid through memories: "II need my memories, they are my documents.", 25

21. "Schwitters also exteriorized parts of his own body and incorporated them into the interior of tunnels or architectural shell. Schwitters placed hair, nail parings and his own urine in small containers throughout the project." Mansoor, "Kurt Schwitters' Merzbau: The Desiring House," 2005, 59.

22. H. Szeeman, "The Propensity for the Total Work," in Lotus International, no.123 (Editoriale Lotus, 2005), 18.

23. The seventh house is not identified by Bourgeois.

24. B. Colomina, Doble Exposición: Arquitectura a través del Arte (trans.) Alfredo Brotons (Madrid: Akal, 2006), 184.

25. Bourgeois cited in J. Frémon, Louise Bourgeois femme maison (Paris: L’ÉCHOPPE, 2008), 25. 
This is an important statement for Bourgeois: she embroidered it in red thread. Cloth, needles and stitches were also part of her world. ${ }^{26}$

Bourgeois was an exiled artist, an émigré - which was not uncommon at the time, in "[...] Manhattan, Duchamp, Breton, Le Corbusier, Amédée Ozenfant, and Frederick Kiesler all lived nearby." 27 So did Louise Bourgeois. "We [Joan Miró and Bourgeois] would dine together at Pierre Matisse's on East 96th Street, along with [Roberto] Matta, Le Corbusier, the filmmaker Thomas Bouchard, Rufino Tamayo, ${ }^{28}$ the composer Edgar Varèse and his wife Louise (the translator), and José Luis Sert [Josep Lluís Sert]. ${ }^{, 29}$ In 1938 she and her husband, Robert Goldwater, moved from Paris to New York. A few years after, in the 1940s, Louise Bourgeois invented a character, the femme maison (see Figure 2). According to Mignon Nixon, this femme maison character portrays " $[\ldots]$ the predicament of a woman artist and mother, homesick in exile - carrying her house on her head - trying to make it as a surrealist in New York." 30 This expression "carrying her house on her head" exposes, in a way, Louise Bourgeois as a woman and as an artist. Femme maison: half woman, half building. Lower part of the body naked. Sex exposed. Jean Frémon, uses an expression from Marie-Laure Bernadac, a clear formulation: "Femme maison is a mixture of architecture and flesh." 31 Frémon goes on to use contradictory expressions in explaining the nature of this femme maison, such as: organization on organic; soft tissue on a harder one; the disquieting and the secure. The terms proposed herein: uncanny, homely unhomely. A restless woman that breathes in and out, through her architectural torso and head: architecture as a homely unhomely place.

26. Her parents Joséphine Bourgeois and Louis Bourgeois owned a gallery and restoration workshop for historical tapestries.

27. M. Nixon, Fantastic Reality: Louise Bourgeois and a Story of Modern Art (Cambridge: MIT Press, 2005), 18.

28. Louise Bourgeois, Juan Miró, Roberto Matta, Rufino Tamayo and Le Corbusier all belonged to the group of artists associated to Atelier 17 in New York (1940-1955).

29. L. Bourgeois, "Native Talent," in Louise Bourgeois: Destruction of the Father Reconstruction of the Father. Writings and Interviews 1923-1997 (ed.) M. L. Bernardac and H. Obrist (London: Violette Editions, 1998a), 272.

30. Nixon, Fantastic Reality: Louise Bourgeois and a Story of Modern Art, 2005, 56.

31. Frémon, Louise Bourgeois femme maison, 2008, 11-12. 


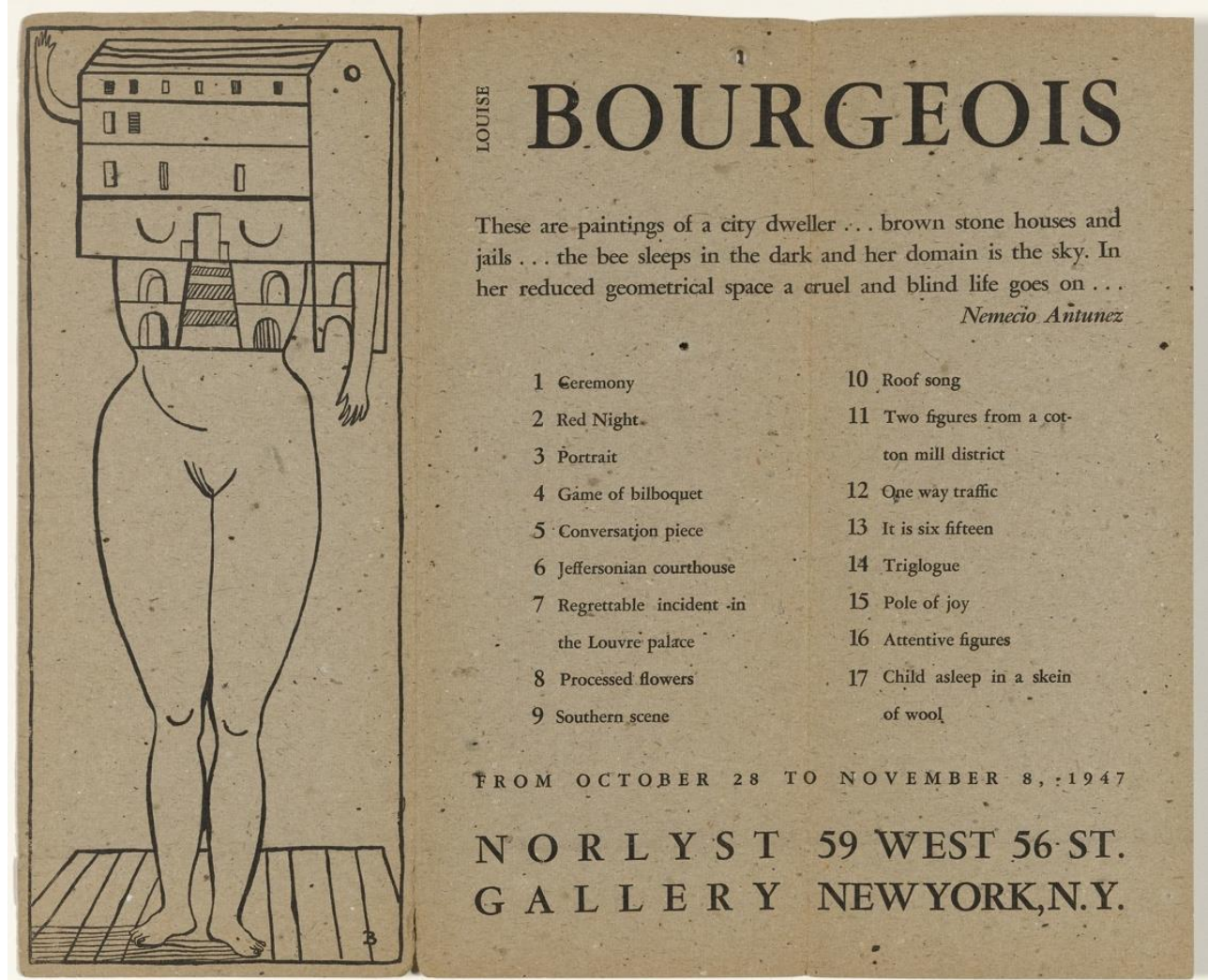

Figure 2. Louise Bourgeois, Femme Maison (Exhibition Brochure for "Louise Bourgeois: Paintings" on View at Norlyst Gallery, New York from 10/2811/8/1947), 1947, Line block, Texture, Wove Paper, 24x30cm

Source: Museum of Modern Art (MoMA), New York (Cat. No. 548.1).

Femme maison is body and soul - as it is architecture and flesh. An alien (ated) body and soul. "Punning doubly on housewife and femme fatale, [...].",32

Nixon states:

For in the image of the femme maison, in contrast to Mannequin, ${ }^{33}$ something is happening inside, upstairs, where she lives. The woman is thinking, talking, working, or perhaps she dreams. Unlike the rigid poses of the woman as fetish, these are the active gestures of the subject who lives in and through her body $[\ldots]^{34}$

This house-woman was portrayed by Bourgeois in different situations and scenarios; ${ }^{35}$ first during the 1940 s, and later, in the 1980 s, she returned to the

32. Nixon, Fantastic Reality: Louise Bourgeois and a Story of Modern Art, 2005, 53.

33. Nixon here is referring to André Masson's Mannequin, 1937, an art piece in which he depicts the Surrealist fascination with fetishism.

34. Nixon, Fantastic Reality: Louise Bourgeois and a Story of Modern Art, 2005, 67.

35. Femme maison with no arms and with smoke coming out of the chimney for hair; femme maison with a neoclassical style building for her head; with an apartment building for her head and torso - with legs spread wide; with no hair or with abundant long hair; with breasts as part of the building; with no breasts; with her sex explicitly revealed or with no sex; 
subject through sculpture and, again, through drawing - in a revision of her most iconic Femme Maison drawing. Five years before Bourgeois's death she was still intrigued by this house-woman - she has stayed with her for most her life, and one can speculate that she and her, or her and she, were one and the same person, Louise. In 2005 her femme maison was depicted as a soft sculpture in white fabric with no head, no arms, legs amputated at the knees, voluptuous breasts, and with a house on her stomach - an external growth. As if the house has already been swallowed, to the point that the head, in the form of the house, now grows out of the guts. Like a creature that is emerging out of herself - that creature being her own self. Her own head, as her own body inside out, as a house. Swallowed. In 1985 Bourgeois painted a femme maison in what appears to be an ambiance of blue skies and smoke: Femme Maison/To eat or to Be Eaten is its title.

Perhaps this is a matter of interiority - a woman "who lives in and through her body". Maybe her legs, her sex, her arms and even, sometimes, her hair are just there to reinsure us that she is undoubtedly a she - although Bourgeois, speaking about the days when she was drawing the Femme Maison, refers that she, the woman, "did not yet have enough poise or objectivity simply to say, 'Don't ask me such a question"”, the question being: "Are you male or female?"36 Maybe the woman is in fact the house, the whole of the house - a swallowed house emerging from the head and torso as flesh, as body, as woman. As an intrabody that comes to the fore.

Her belated recognition, during the 1980s, and the longevity of Bourgeois's career - she worked up until her death - makes the artist, herself, almost a character. Louise Bourgeois is a femme maison in every sense of the term. In her final years, her old "implausible" body was, again, herself, her bodywork, her house - 347 West, 20th Street, New York. As it was. As it is. Small, fragile, full. She enabled the exposure of the perfect imperfection of her body. An ideal body. Like her work, like her houses and studios. Jean Frémon likens her studio in Brooklyn, in 1992, to Ali Baba's cave ${ }^{37}$ - full of wonders and treasures, but a cave nonetheless.

Ulf Küster recalls Bourgeois's Chelsea house in New York:

She seldom left the house during the decade prior to her passing. She rarely entered the room of her husband, the renowned art historian Robert Goldwater, after his death in 1973; she had thus turned herself into a prisoner in her own home. Her bed appeared tiny to me and seemed as if it had been built into a wall of books, primarily nineteenth-century editions of French literature, Victor Hugo, Honoré de Balzac, and others. The small washstand on a thin mount reminded me of her sculptural group Maisons

or even as a fallen femme maison - where the building almost takes the place of wings... and then there are the sculptures with a house as head; or with a house on the belly; or....

36. L. Bourgeois, "Statements 1979," in Louise Bourgeois: Destruction of the Father Reconstruction of the Father. Writings and Interviews 1923-1997 (ed.) M. L. Bernardac and H. Obrist (London: Violette Editions, 1998c), 114.

37. Frémon, Louise Bourgeois femme maison, 2005, 42. 
fragiles from 1978. And Jerry [Gorovoy] pointed out to me that the house itself is in fact also a "primordial cell," the model on which she based the spatial installations she characterized as "cells," with which she was particularly occupying herself in nineteen-nineties. ${ }^{38}$

And Jean Frémon recalls it too. Frémon talks about an eerie experience of his in the 1980s in the basement of Louise Bourgeois's Chelesa house. While visiting Louise, Frémon was invited to visit her basement. Almost thirty years later, he tells us about the basement's stone flooring, big brilliant round stones - like century-old rolling stones taken out of a river or an ocean floor. He tells us how he felt uneasy, he felt he was in a cave under the ocean. He felt that he was inside of a Louise Bourgeois sculpture. Walking through her work. ${ }^{39}$ For some reason Frémon has written about the basement of Bourgeois's house in Chelsea, and her studio, in Brooklyn - as if these spaces were themselves a cavity in Bourgeois's own body; as if these spaces domiciled themselves in Bourgeois's own thought, own mind. In her own head.

Frémon takes one inside the femme maison. One sees nothing else, just the inside of her head. Everything is her head. Legs, arms, sex, hair, building everything exists in a zone of indiscernibility. This zone resides in an interior place, with no windows - like, to use a Deleuzian term, a "great Baroque montage." ${ }^{, 0}$ Everything vibrates and resonates. Heavy fabrics, old clothes, bones, every piece remainshung inspace, shaping this particular cell, a "primordial cell". This closed place is a place of accumulation. It's a place of connections - interconnections, intra-connections - "“I do, I undo, I redo,",41 says Louise Bourgeois; "[...] folding, unfolding, refolding," 42 says Deleuze. Bourgeois's house as an incubator for her memories and art. Her house is her head (body) as her head (body) is her art work. Everything rests in indiscernibility. We are inside Louise Bourgeois's head. We are in the flux of time. An intrabody that spawns an intraworld.

\section{Fantastic Reality and the Desiring-Machines}

"[...] what has changed now is the organization of the home and its nature."43

Through Kurt Schwitters's folded intraworld, and through Louise Bourgeois's anthropomorphic folded body, intrabody, both artists are offering their intrastructures. But we have to cut deeper inside the Merzbau's layers and inside Bourgeois's "fragile" substance. Like her, we must dig the needle into the flesh to reveal the machinic in both artists' work. From monadology to "nomadology."

38. U. Küster, Louise Bourgeois (Osfildern: HatjeCantz, 2011),13.

39. Frémon, Louise Bourgeois femme maison, 2005, 18.

40. Deleuze, The Fold, 2006,4.

41. Bourgeois cited in Frémon, J., Louise Bourgeois femme maison, p. 14

42. Deleuze, The Fold, 2006, 158.

43. Ibid, 158. 
The anthropomorphic body is itself already a machine. It processes the associative flow. The mouth will cut speech, air, milk [food]. Likewise, it will afford the conditions of possibility of that material passage; it provides a set of thresholds and surfaces that enable the passage of matter, of stuff. The anthropomorphic body, then, is both armature, machinic system, and material flow. [...] The body is one site among many where the machine and the endless anorganic vitalism of surfaces and flows converge. ${ }^{44}$

Mansoor's depiction, in the above quotation, of the anthropomorphic body - as a machine - aligns with our vision of Louise Bourgeois's "body of work." However, both artists knit with the machinic's ideal. Indeed, Mansoor's description of that body is directly correlated with Kurt Schwitters' oeuvre.

Mansoor notes that in a short essay entitled "Balance Sheet - Program for Desiring-machines, ${ }^{, 45}$ Gilles Deleuze and Félix Guattari refer to Kurt Schwitters' Merzbau as "[...] the desiring house, the house machine of Kurt Schwitters which sabotages and destroys itself, where its constructions and the beginning of its destruction are indistinguishable." 46 "For Deleuze and Guattari, the compositional, anti-structural set of relations, cuts and connections that the Merz produces constitute it as a desiring-machine." ${ }^{, 7}$ Likewise, Rosalind E. Krauss was one of the first writers on Bourgeois to deeply intersect her and Marcel Duchamps's oeuvres with the desiring-machine, arguing that both artists were preoccupied with the logic of part-object: "Needing something to exist materially, something that would act in the physical world, she turned to sculpture. And seeking what she called 'fantastic reality,' she sought the condition of the desiring machine." "48

If, in the early $20^{\text {th }}$ century, the machine was very much in the air $d u$ temps, these arguments concerning the relationship between the desiringmachine, Kurt Shwitters' Merzbau and the logic of part-object inherent to Louise Bourgeois's thought go well beyond the scope and spirit of that period. Kurt Schwitters' ideas re-emerge in contemporary thought, while Louise Bourgeois has established herself as a pivotal artist mediating between Modernism and contemporaneity. As Mansoor and Nixon states, respectively:

Schwitters' machinic collage constructions, and later the Merzbau, locate his attempt to come to terms with this environment [the machine in Modern art production]. It was in 1923, upon his return from the tour of Holland with Van Doesburg, that he began working on the Merzbau full time.

44. Mansoor, "Kurt Schwitters' Merzbau: The Desiring House,” 2005, 57.

45. Addended to the 1997 edition of Anti-Oedipe. Gilles Deleuze and Felix Guattari, "Balance - Program for Desiring Machines," in Lotus International, no.123 (Editoriale Lotus, 2005), 117-35.

46. Gilles Deleuze and Felix Guattari, "Balance Sheet - Program for Desiring-machines," in Semiotexte 2, no.3 (1977), 129 in Mansoor "Kurt Schwitters' Merzbau: The Desiring House," 2005, 54.

47. Mansoor, “Kurt Schwitters' Merzbau: The Desiring House," 2005, 54.

48. Rosalind E. Krauss, "Louise Bourgeois: Portrait of the Artist as Fillette," in Bachelors (ed.) Krauss (Cambridge: MIT Press, 1999), 66. Krauss cited in Nixon, Fantastic Reality: Louise Bourgeois and a Story of Modern Art, 2005, 110. 
Paradoxically, he also claims that, by 1925, he hoped for "a rigor, a simplification and universal expression."

This set of collaborations and claims contiguous to his peers evince a selfinscription into those practices, which permitted Schwitters to internalize, or introject, an abstract productive machine. ${ }^{50}$

[...] her [Louise Bourgeois] break with painting and corresponding move into the more concrete domain of fantastic reality as a confrontation with two works - two monuments - of twentieth-century art: André Breton's 1924 "Manifesto of Surrealism" and Marcel Duchamp's The Bride Stripped Bare by Her Bachelors, Even, known as the Large Glass (1915-1923). ${ }^{51}$

In an interview with Donald Kuspit Louise Bourgeois states: "Marcel Duchamp could have been my father." 52 This is a complex statement, given the difficult relationship between Bourgeois and her father Louis; but then again, the relationship between the two artists was also not easy. He Disappeared into Complete Silence, a suite of nine engravings paired with short texts that was published as a limited-edition book in $1947^{53}$ (see Figure 3), marked a rupture with Louise Bourgeois's painting work and opened up a path to her sculptural output. The seventh plate, or engraving, reveals an architectural chaotic machinery. A twinned apparatus, like skyscrapers, seemingly out of control two architectural mechanic bodies in collision with each other. Bodies as partobjects in (dis)connection.

49. Cited in John Elderfield, Kurt Schwitters (New York: Thames and Hudson, 1985), 126.

50. With quotation by Kurt Schwitters in Elderfield, Kurt Schwitters, 1985, 126; Mansoor, “Kurt Schwitters' Merzbau: The Desiring House,” 2005, 55-56.

51. Nixon, Fantastic Reality: Louise Bourgeois and a Story of Modern Art, 2005, 8.

52. Donald Kuspit, Bourgeois: An Interview with Louise Bourgeois (New York: Vintage Books, 1988), 31 in Nixon, Fantastic Reality: Louise Bourgeois and a Story of Modern Art, 2005, 13.

53. First published in 1947 by Gemor Press as a limited-edition book of engravings made at Stanley William Hayter's Atelier 17, New York, with an introduction by Marius Bewley (assistant to Peggy Guggenheim). 


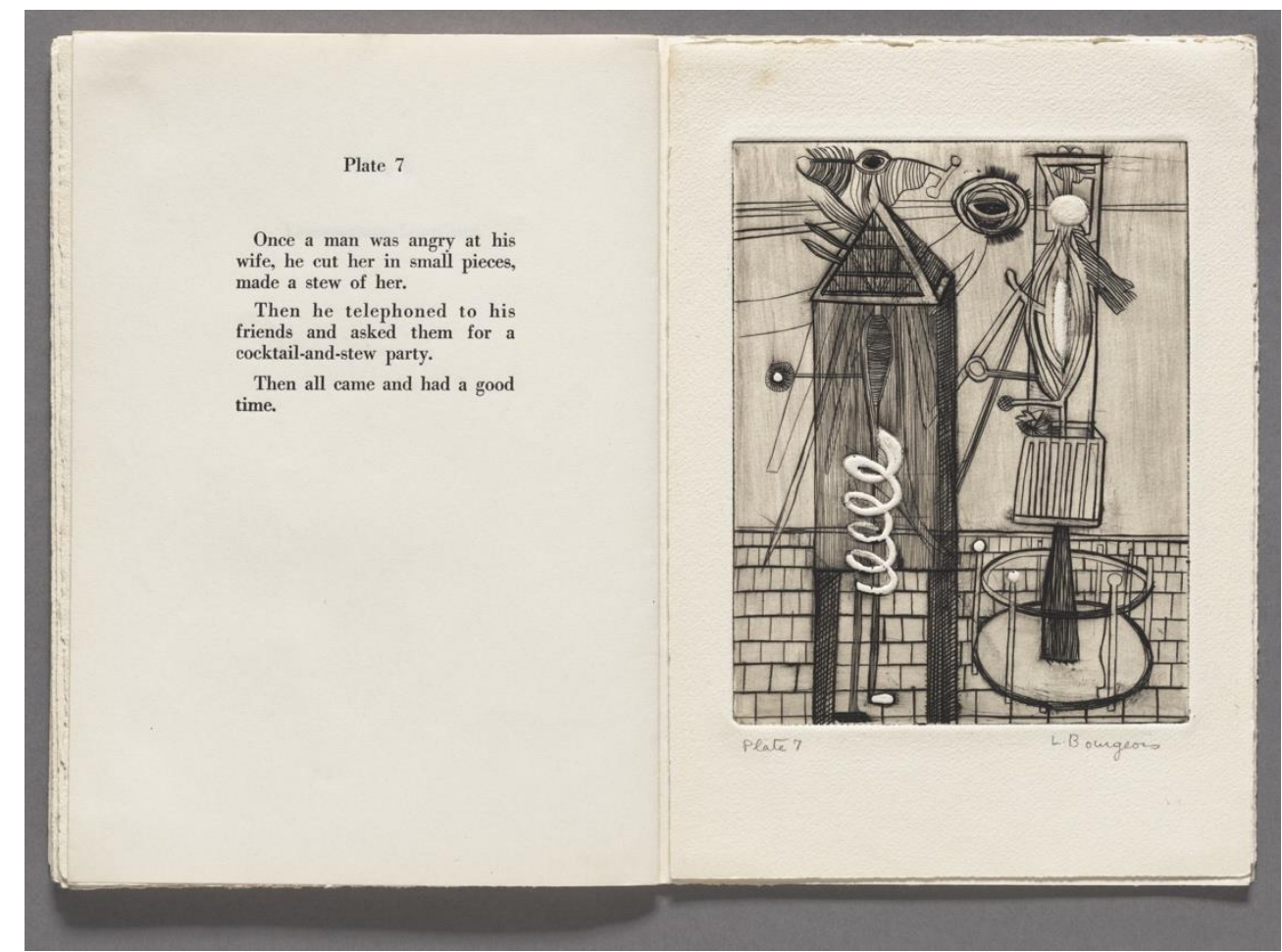

Figure 3. Louise Bourgeois, Plate 7 of 9, from the Illustrated Book, He Disappeared into Complete Silence, First Edition, Example 1, 1947. Engraving and dry point, with Scorper, Plate: $17.8 \times 13.8 \mathrm{~cm}$

Source: Museum of Modern Art (MoMA), New York (Cat. No. 995.1/X).

The accompanying story by Louise Bourgeois:

Once a man was angry at his wife, he cut her in small pieces, made stew of her.

Then he telephoned to his friends and asked them for a cocktail-and-stew party.

Then all came and had a good time. ${ }^{54}$

This marital collision, as Nixon writes, “[...] offers a comic gloss on Marcel Duchamp's La Mariée mise a nu par ses célibataires, même (The Bride Stripped Bare by Her Bachelors, Even), also known as the Large Glass. Even more, it recalls Duchamp's notes and diagrams for his work collected in the Green Box and published in 1934." W5 With Duchamp's Le grand verre (Large Glass), an unfinished work that preoccupied him for eight years, one is in the realm of pure thought. In the realm of intellectual experiments: as if the time devoted to it was itself, as a duration, a source of the contents of the work. This double glass panel operates as an artistic apparatus or device, a non-machine machine. Louise Bourgeois knew Duchamp well, and of course, was also very well acquainted with his work - after all he could have been her "father". So, one

54. Bourgeois, He Disappeared into Complete Silence (Paris: Éditions Dilecta, Facsimiled edition), 2008a.

55. Nixon, Fantastic Reality: Louise Bourgeois and a Story of Modern Art, 2005, 94-96. 
can imagine Bourgeois extracting the diagrammatic dimension of Duchamp's work and spiralling it into a process of decay and engulfment. The machine is now engulfed by the imperfect, out of control, human body - and its imperfect stories -, and repaid as an architectural chaotic machinery. Now the body is architecture, and now architecture and body are both machinery. Bourgeois shifted the human body to an architectural/mechanical erected one - an obscure body as part-object. Fantastic Reality.

Kurt and Louise. Kurt Schwitters: nailing layers. The continuity - on and on - remains with one and the same work. One house infected by a spreading virus. Inside to outside. The folds are produced through the layers, in continuous succession. Clean folds in a non-systemic display of relics and objets trouvés. The whole as a body constituted by part-objects. Louise Bourgeois: do, undo, redo. The continuity - on and on - passes from work to work. The whole as continuity, including her houses, including herself. The anthropomorphic body as part-object: the artists' grotesque bodies are often limbless, as if amputation created a state of connection. Connect, unconnect and reconnect. The cuttings, even the scars - or stitches - open up a way to these interconnections. Bodies as part-objects are a whole through this state of connection, as non-mechanical machinic machines, as desiring-machines.

"There is no point in wondering about the utility or non-utility, about the possibility or impossibility of such desiring-machines. Impossibility (and then only rarely) and inutility (and then only rarely) are revealed solely by autonomous artistic representation." 56

In the above quotation, Deleuze and Guattari refer to a Bruno Bettelheim case study through the name of a character: little Joey. ${ }^{57}$ A boy "who can live, eat, defecate, and sleep only if he is plugged into machines provided with motors, wires, lights, carburetors, propellers, and steering wheels: an electrical feeding machine, a car-machine that enables him to breathe, an anal machine that lights up." ${ }^{58}$ Little Joey cries: "Connecticut, Connect-I-Cut!" ${ }^{59}$ Kurt Schwitters clarifies: "I am a painter and I nail my pictures together." 60 Louise Bourgeois affirms: "'I do, I undo, I redo.",61

"Connect-I-Cut!" "I nail my pictures together." "I do, I undo, I redo." We are in the realm of the machinic.

56. Deleuze and Guattari, "Balance - Program for Desiring Machines," 2005, 62.

57. In his study The Empty Fortress, Bruno Bettelheim describes a specific situation - as autism - of a young child, Little Joey. This study, and the child, are used by Deleuze and Guattari in their book Anti-Oedipus: Capitalism and Schizophrenia (1972).

58. Deleuze and Guattari, Anti-Oedipus: Capitalism and Schizophrenia (trans.) Robert Hurley, Mark Seem and Helen R. Lane (London: Bloomsbury Academic, 2004), 51.

59. Ibid.

60. Kurt Schwitters in Hans Richter, Dada art and Anti-Art (trans.) David Britt (London: Thames and Hudson, 1965), 137. Schwitters cited in Mansoor, "Kurt Schwitters' Merzbau: The Desiring House," 2005, 57.

61. Bourgeois cited in Frémon, Louise Bourgeois femme maison, 2008, 14. 


\section{"Meta-Machines" in a Meta-Baroque World}

Stefan Boeri points out that "[...] we should conceive of the Merzbau as a sort of spatial device, which is in fact working in our contemporary environment, trying to complexify these realities, to open all of realities to the future, to introduce the notion of uncertainty." 62 He goes as far as to argue that the notion of device, or apparatus, is "[...] today absolutely crucial in the architectural discussion." $" 63$

The new machines - or meta-machines - strive for new technologies. An architectural apparatus- belonging to a meta-Baroque world - is one that is opened up. Its background is a transdisciplinary mesh, the weaving of which is now beginning. This mesh awaits other subjects, or disciplines, for instance the neurosciences. The presence of the neurosciences in the world of architecture can be, in this context, essential: it opens up a path to the conception of the mind that extends beyond the body - an intrabody in activity in an intraworldthrough experiments with the body and the machine. Or rather, a machine as a living extension of the body; or a machine as a whole, a meta-machine. Here this meta-machine will take the form of habitable space, in continuous connections and reconnections with the inhabitant - an architectural apparatus. This architecture requires a reactive body that acknowledges its inner being, an intrabody, not a dreaming one, but more a spellbound one, like Bourgeois's: "I don't dream. You might say I work under a spell, I truly value the spell."64 Inert matter activated through its connection with an active body. Ignited. Here one needs the integration of the new technologies (even if only in the theoretical field) with a view to constructing a non-standard architecture. Robotics and the use of intelligent materials have given rise to theoretical studies, prototype production and embryonic experiments (above all for building facade or skins) in the field of architecture. However, we need these technologies as ideas. "[A] technical application can be considered as an idea: not an idea in someone's mind, but an idea in matter." 65 We need weight in the volatile matter of the new technologies. ${ }^{66}$ We need them to operate in the realm of the desiringmachine, but also to extrapolate it. We need trajectivity. We need it to be mobile at its core. And we need to be artists to ignite - to set alive - a meta-Baroque architectural apparatus.

This takes us back to Deleuze and Guattari when they argue that we need the autonomous artistic representation to reveal the true nature of the desiring-

62. S. Boeri, "The Merzbau as a Spatial Device," in Merz World: Processing the Complicated Order (ed.) A. Notz and H. Obrist (Zurich: JRP Ringier, 2007), 13.

63. Ibid, 14.

64. Bourgeois, "Taking Cover: Interview with Stuart Morgan," in Louise Bourgeois: Destruction of the Father Reconstruction of the Father. Writings and Interviews 1923-1997 (ed.) M. L. Bernardac, M. L. and H. Obrist (London: Violette Editions, 1998b), 160.

65. S. Portanova, Moving without a Body: Digital Philosophy and Choreographic Thoughts (Cambridge: MIT Press, 2013), 8.

66. "Deleuze and Guattari are careful to disentangle this operational mode of the desiringmachines from any crude analogy to a mechanical gadget, an industrial apparatus, or an electronic device.” Mansoor, “Kurt Schwitters’ Merzbau: The Desiring House,” 2005, 54. 
machine, and as they argue, there is no point in wondering about that true nature. We are going forward in time. This is our time. And we need weight and depth in our time. We need ideas in matter. We need the obscurity that resides in the depths of our body to drain into the depths of the world. We need.

And here is Louise Bourgeois to round off the argument: "This has to do with pivoting on an axis, going around and round... So, it is a mechanical thing. By mechanical you mean something that works. I am interested in cars because they self-propel themselves for reasons that are reasonable and mechanical. So, this is it: How am I going to be self-operating all by myself? Well, I can do that if I can invent something that keeps me going."67 This schizoid pattern of speech ("how am I going to be self-operating all by myself") - a Duchampian logic - evokes the phantasy [phantasy, with ph, in Melanie Klein's view, arises at a prelinguistic stage of experience, in infancy], as Nixon ${ }^{68}$ points out, of being a part-object machine. Louise Bourgeois, as a meta-Barroque individual, being a part-object machine. Being part of a meta-machine. Living-in-a-livingobject.

In his poem My House (1945) Kurt Shwitters writes:

I am to build a house of ice,

Because it is more liquid.

I build all my thoughts into this house.

There are the walls and windows

And all the furniture ... and me. ${ }^{69}$

Louise Bourgeois writes, on fabric:

The Bièvre River.

It was because of that river that we bought the

house in Antony. The Bièvre cut across the garden

in a straight line. With the soil from that river

we planted geraniums, masses of peonies, and beds of asparagus. There were hawthorns,

pink and white, and purple tamarisk, and trees of cherries. Pears and apples

grew on espaliers on the stone wall.

There were boxwoods. And honeysuckle

that smelled so sweet in the rain.

I had gone back to

Antony with my children

to see the house where I had grown up and where the river Bièvre flowed through the backyard.

67. L. Bourgeois and L. Rinder, Louise Bourgeois: Drawings and Observations (University of California, Berkeley: University Art Museum and Pacific Film Archive, 1995), 83.

68. Nixon, Fantastic Reality: Louise Bourgeois and a Story of Modern Art, 2005, 109.

69. Luke, Kurt Schwitters: Space, Image, Exile, 2014, 147. 
But the river was gone. Only the trees

that my father had planted

along its edge

remained as a witness. ${ }^{70}$

On paper, imprecisely hand written, she adds: "Nothing to remember!" "auto. toto total. Recall." "my Memories are moth eaten.,"71

\section{Conclusions}

Linking architecture and other disciplines is an age-old desire but putting that desire into practice has not always been an easy or linear task. Building relationships where there are no direct correspondences in terms of common philosophical concepts, methods and rules is an undertaking where it is easy to fall off the charted area of the obvious into territory where everything becomes susceptible to errors. But still, we strive to achieve this desire. The avant-gardes of the $20^{\text {th }}$ century opened up new fields of discussion on transdisciplinarity, and since the turn of the millennium we have been witnessing a critical discourse that justly seeks - or needs at its core - the crossing of disciplines.

We need the artistic world in our contemporaneity. We need the philosophical word in our contemporaneity. As said above, we need weight in the volatile matter of the new technologies. We need ideas in matter.

We have to go deep inside of our souls - why not inside of our monads? and go beyond the dark Deleuzian Baroque House, moving it - through trajectivity - into an extrapolation of itself: a meta-Baroque House. This house resides in our intrabodies and through a reactive architecture it can come to the fore and "self-propel themsel[f] for reasons that are" not so "reasonable and mechanical" but machinic. In this way, we can imagine our ideas in matter, converting inert substance and activating it through its inter-connections in continuation with an active body.

I can became a connective part object, as a desiring-machine, and I can become my house; and my house can become me, a connective part object, as a post desiring-machine, a living machine, a living house-machine; an architectural apparatus.

We must not forget, we need to be artists to ignite - to set alive - a metaBaroque architectural apparatus.

Like Kurt Schwitters and Louise Bourgeois, I would become my own address.

70. Bourgeois, Ode à la Bièvre (New York: Zucker Art Books, 2007). Based on a unique lithograph and dye on fabric book of the same title made in 2002 by Louise Bourgeois. Bourgeois, L., Ode à la Bièvre.

71. Bourgeois, Nothing to Remember (Zürich: Steidl Hauser \& Wirth, 2008b). 


\section{Acknowledgments}

This paper is funded by national scientific funding through FCT - Fundação para a Ciência e a Tecnologia, under Project UID/AUR/04026/2013.

\section{Bibliography}

Boeri, S. "The Merzbau as a Spatial Device." In Merz World: Processing the Complicated Order. Edited by A. Notz and H. Obrist. Zurich: JRP Ringier, 2007.

Bourgeois, L. and L. Rinder. Louise Bourgeois: Drawings and Observations. University of California, Berkeley: University Art Museum and Pacific Film Archive, 1995.

Bourgeois, L. "Native Talent." In Louise Bourgeois: Destruction of the Father Reconstruction of the Father. Writings and Interviews 1923-1997. Edited by M. L. Bernardac and H. Obrist. London: Violette Editions, 1998a.

. "Taking Cover: Interview with Stuart Morgan." In Louise Bourgeois: Destruction of the Father Reconstruction of the Father. Writings and Interviews 1923-1997. Edited by M. L. Bernardac, M. L. and H. Obrist. London: Violette Editions, 1998b.

. "Statements 1979." In Louise Bourgeois: Destruction of the Father Reconstruction of the Father. Writings and Interviews 1923-1997. Edited by M. L. Bernardac and H. Obrist. London: Violette Editions, 1998c.

. Ode à la Bièvre. New York: Zucker Art Books, 2007.

He Disappeared into Complete Silence. Paris: Éditions Dilecta, Facsimiled edition, 2008a. . Nothing to Remember. Zürich: Steidl Hauser \& Wirth, 2008b.

Colomina, B. Doble Exposición: Arquitectura a través del Arte [Double Exposure: Architecture through Art.] Translated by Alfredo Brotons. Madrid: Akal, 2006.

Combes, M. Gilbert Simondon and the philosophy of the transindividual. Cambridge: MIT Press, 2012.

Deleuze, G. and F. Guattari. Anti-Oedipus: Capitalism and Schizophrenia. Translated by Robert Hurley, Mark Seem and Helen R. Lane. London: Bloomsbury Academic, 2004.

Deleuze, G. and F. Guattari. "Balance - Program for Desiring Machines." In Lotus International, no.123.Editoriale Lotus, 2005.

Deleuze, G. The Fold. Translated by Tom Conley. London, Continuum, New York, 2006.

Elderfield, John. Kurt Schwitters. New York: Thames and Hudson, 1985.

Elger, D. "The Merzbau and Expressionist Architecture." In Merz World: Processing the Complicated Order. Edited by A. Notz and H. Obrist. Zurich: JRP Ringier, 2007.

Frémon, J. Louise Bourgeois femme maison [Louise Bourgeois House Woman.] Paris: L'ÉCHOPPE, 2008.

Küster, U. Louise Bourgeois. Osfildern: Hatje Cantz, 2011.

Lach, Friedhelm. Kurt Schwitters, Das Literarische Werk 5. Cologne: DuMont Schauberg, 1973-1981.

Luke, M. R. Kurt Schwitters: Space, Image, Exile. Chicago: University of Chicago Press, 2014.

Mansoor, J. "Kurt Schwitters' Merzbau: The Desiring House." In Lotus International, no.123. Editoriale Lotus, 2005.

Nicolin, P. "Merzbau." In Lotus International, no.123.Editoriale Lotus, 2005.

Nixon, M. Fantastic Reality: Louise Bourgeois and a Story of Modern Art. Cambridge: MIT Press, 2005. 
Orbist, H. "The Merzbau as a Paradigm of Interior Complexity." In Merz World: Processing the Complicated order. Edited by A. Notz and H. Obrist. Zurich: JRP Ringier, 2007.

Portanova, S. Moving without a Body: Digital Philosophy and Choreographic Thoughts. Cambridge: MIT Press, 2013.

Rothenberg, J. and P. Joris, P. eds. Kurt Schwitters: PPPPPP Poems, Performance, Pieces, Proses, Plays, Poetics. Cambridge: Change, 2002.

Szeeman, H. "The Propensity for the Total Work." In Lotus International, no.123. Editoriale Lotus, 2005.

Vidler, A. Warped Space: Art, Architecture, and Anxiety in Modern Culture. Cambridge: MIT Press, 2001.

Virilio, P. "Gravitational Space." In Traces of Dance. Edited by L. Laurence. Paris: Editions Dis Voir, 1994. 